\title{
Constantin von Economo's 90th death anniversary
}

\author{
O 90 aniversário da morte de Constantin von Economo \\ Hélio Afonso Ghizoni TEIVE ${ }^{1,2}$, Fernando Spina TENSINI', Plínio Garcia LIMA', Carlos Henrique Ferreira \\ CAMARGO²
}

\begin{abstract}
The year of 2021 marks 90 year since the death of the neuroscientist Constantin von Economo, whose research in various areas was extremely relevant for the field of neurology. He described lethargic epidemic encephalitis, published an atlas of the cytoarchitecture of the human cerebral cortex, and conducted multiple studies in neuroanatomy, neurophysiology, and clinical neurology. Von Economo's genius extended into other nonmedical fields such as aeronautics, and he had renowned artistic skills.
\end{abstract}

Keywords: History; Neurology; Parkinson Disease, Postencephalitic; Influenza Pandemic, 1918-1919.

\section{RESUMO}

O ano de 2021 marca o 90 aniversário da morte do neurocientista Constantin von Economo, ou Constantin Freiherr (Barão) von Economo. Von Economo realizou várias pesquisas de grande relevo na área da neurologia, com a descrição da encefalite letárgica epidêmica, a publicação do atlas sobre a citoarquitetura do córtex cerebral humano, além dos seus múltiplos estudos em neuroanatomia, neurofisiologia, bem como na neurologia clínica. A genialidade de von Economo se estendeu para outras áreas não médicas, com o seu grande interesse em aeronáutica, como piloto de avião, além dos seus reconhecidos dotes artísticos.

Palavras-chave: História; Neurologia; Doença de Parkinson Pós-Encefalítica; Influenza Pandêmica, 1918-1919.

\section{INTRODUCTION}

Amid the global COVID-19 pandemic, neurological complications including acute encephalopathy resulting from severe acute respiratory syndrome coronavirus 2 recall the cases of encephalitis lethargica(EL) described in 1916 and 1917, which were initially related to the Spanish flu ${ }^{1}$. These cases described more than 100 years ago by Constantin von Economo aroused major research interest, particularly on the etiopathogenic mechanisms of this illness, which remain enigmatic (Figure 1) ${ }^{1}$. The description of these cases has made von Economo famous, but his contributions to neurology were much broader, and led him to three nominations for the Nobel Prize in Physiology and Medicine ${ }^{1-4}$. The year 2021 marks the 90th anniversary of von Economo's death.

\section{BARON CONSTANTIN VON ECONOMO (1876-1931)}

Constantin Alexander von Economo (Figure 1) was born on August 21, 1876, in Brãila, Romania. His family, which descended from the Greek aristocracy, moved first to Trieste (part of the Austro-Hungarian Empire at the time) and later to Vienna ${ }^{4-7}$, where von Economo graduated in Medicine in 1901. In 1903 and 1904, he was a resident in internal medicine under Carl Wilhelm Nothnagel. As his interest in neuroscience grew, he completed several internships in various countries across Europe. In Paris he attended the neurology services of Pierre Marie, Fulgence Raymond, and Alexis Joffroy; in Germany he interned with Alois Alzheimer and Emil Kraepelin (in Munich), and with Hermann Oppenheim and Theodor Ziehen (in Berlin) ${ }^{4,7-10}$. He also attended other neuropsychiatric services in Nancy

\footnotetext{
1Universidade Federal do Paraná, Hospital de Clínicas, Departamento de Clínica Médica, Serviço de Neurologia, Curitiba PR, Brazil.

2 Universidade Federal do Paraná, Hospital de Clínicas, Programa de Pós-Graduação em Medicina Interna, Grupo de Doenças Neurodegenerativas, Curitiba PR, Brazil.

HAGT(D) https://orcid.org/0000-0002-4045-1178; FST (D) https://orcid.org/0000-0002-2592-2779; PGL (DD https://orcid.org/0000-0001-6143-6666; CHFC (iD) https://orcid.org/0000-0002-3533-0347

Correspondence: Hélio Afonso Ghizoni Teive; Email: hagteive@mps.com.br.

Conflict of interest: There is no conflict of interest to declare.
}

Authors' contributions: HAGT: Conceptualization (Lead), Project administration (Lead), Supervision (Lead), Investigation (Equal), Writing-original draft (Equal); FST, PMGL: Investigation (Equal), Writing-original draft (Equal); CHFC: Writing-review \& editing (Lead).

Received on March 15, 2021; Received in its final form on April 10, 2021; Accepted on April, 15, 2021. 


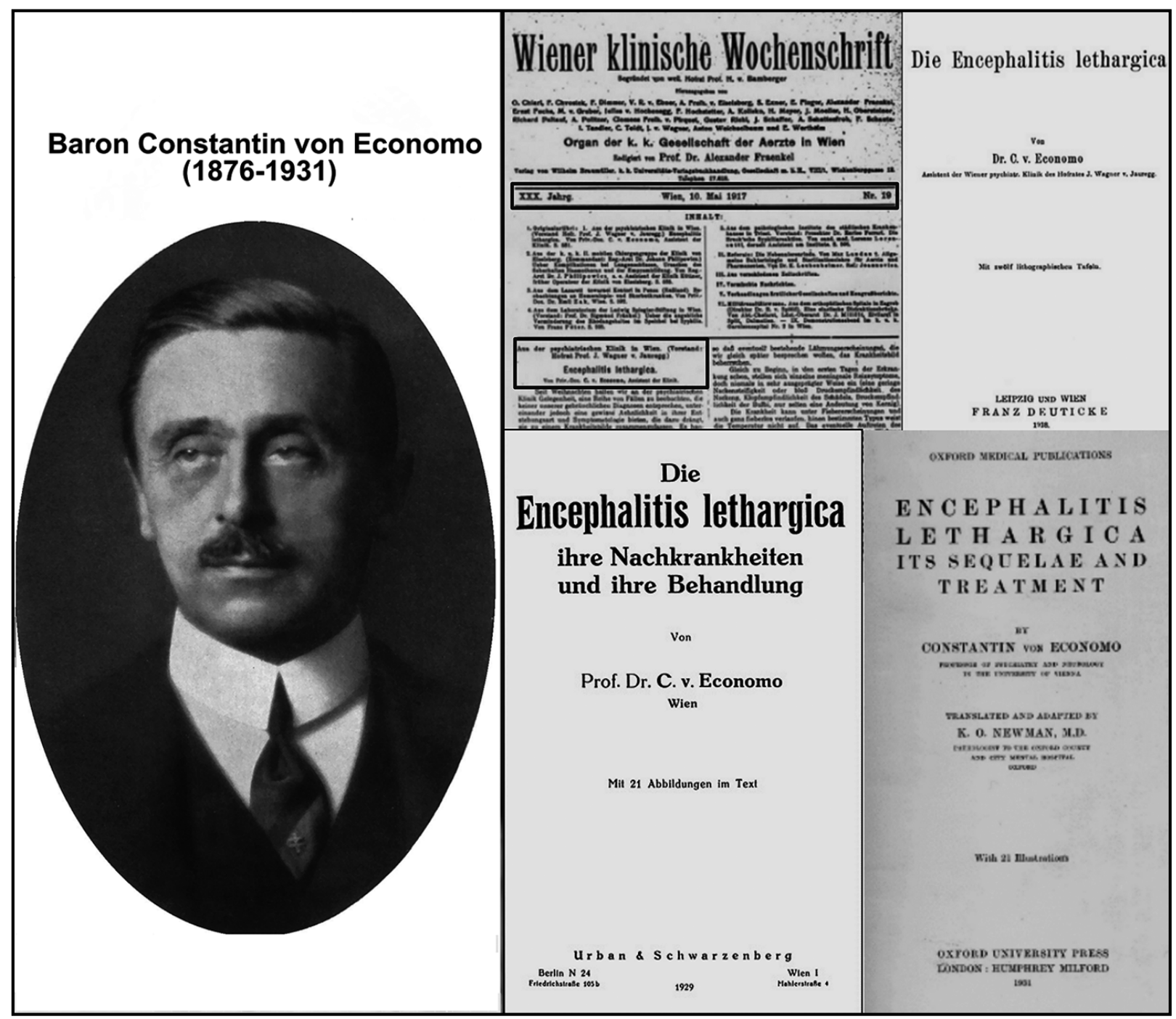

Extracted from https://commons.wikimedia.org/wiki/File:Constantin_von_economo.jpg and https://commons.wikimedia.org/wiki/File:Economo_encephalitis.jpg Figure 1. Combination performed by the authors from von Economo's photo, his publication on lethargic encephalitis ${ }^{11}$, and later publications on the same issue.

(with Hippolyte Bernheim), Strasbourg (Albrecht von Bethe), and in Trieste (Carl Isidor Cori). He returned to Vienna with this experience in the field and worked as an assistant at the Psychiatry and Nervous Diseases Clinic at Vienna's General Hospital from 1906, under the direction of Julius WagnerJauregg (who won the Nobel Prize for Physiology and Medicine in 1927) ${ }^{4,7-10}$. That same year von Economo was granted the title of Baron ("Freiherr") and his name became Constantin Freiherr von Economo. In 1913, he became associate professor of Psychiatry and Neurology at the University of Vienna. In 1919 (at age 43) he married Princess Karoline von SchönburgHartenstein ${ }^{47-10}$. Two years later, von Economo was appointed as full professor of Psychiatry and Neurology at the University of Vienna, where he organized his line of academic research; this culminated in the creation, in 1931, of the Department of Brain Research, which he coordinated. Five months later he died at the age of 55 , from a myocardial infarction complicated by a stroke. He was buried in Trieste $e^{4,-10}$.

\section{MAIN CONTRIBUTIONS TO NEUROLOGY}

Von Economo made very significant scientific contributions to neurology. His paper entitled Die centralen Bahnen des Kauund Schluckactes ${ }^{11}$, the first in his capacity as a graduated physician, is one of the first studies in the history of brain research to attempt to describe the brain centers of mastication and deglutition ${ }^{12}$. In this paper, he had already shown his interest in the functions and anatomical connections of the substantia nigra. He suggested that the coordination and succession of all alimentation movements are performed as a whole in the substantia nigra, with the involvement of cranial nerves ( facial, hypoglossal, vagus, trigeminal) ${ }^{12}$. In 1917, he first published an article in Wiener Klinische Wochenschrift describing cases of a rare disease occurring during 1916-1917, which he defined as lethargic epidemic encephalitis (later known worldwide as von Economo encephalitis) (Figure 1) (4,-13 $^{\text {. Two additional }}$ publications neuropathologically and clinically defined this 
disease ${ }^{4,7-10,14}$. He described the clinical presentation in three forms: somnolent-ophthalmoplegic, hyperkinetic (with chorea, myoclonus, and myorhythmia), and amyostatic-akinetic (characterized by the presence of parkinsonism and at times oculogyric crisis and psychosis) ${ }^{13,14}$. Von Economo also defined the principal neuropathological changes, with special involvement in the midbrain and substantia nigra, as well as the basal ganglia and hypothalamus later ${ }^{13,14}$. In 1925, von Economo and Koskinas published a phenomenal atlas of the cytoarchitecture of the adult human cerebral cortex, defining five structural cortex types and 107 different areas (Figure 2) ${ }^{8-10,15,16}$. This seminal work was a revolutionary presentation of new information in the cytoarchitecture of the cerebral cortex, updating and greatly improving the pioneering works by Meynert and especially Brodmann from 16 years earlier ${ }^{15}$. Von Economo also defined a special type of neuron known as the bipolar spindle neuron (or von Economo neuron) located in the frontoinsular and anterior cingulate cortex ${ }^{8-10,17}$. Observing patients with lethargic encephalitis, who suffered from excessive sleepiness or "craving for sleep", von Economo admitted the possibility of a sleep center. Anticipating our most modern concepts of sleep regulation, he speculated that the sleep center might also be responsible for the "readiness to dream" ${ }^{18}$. Furthermore, he published essential work on movement disorders, with neuropathological studies on Parkinson's disease, the basal ganglia, post-hemiplegic chorea, and Wilson's disease $\mathrm{e}^{4,8-10,19}$. One of his last lines of research addressed evolutionary neuroanatomy, postulating the theory of "progressive cerebration." He investigated neuronal microstructural changes related to what he defined as "elite brains", distinguishing these from "average brains"

\section{VON ECONOMO: A POLYMATH}

Besides his scientific career, von Economo was a balloonist and an accomplished pilot. He flew balloons and later became an airplane pilot, and in 1912 became the first Austrian to obtain an international pilot's diploma ${ }^{4,7,9,10}$. He served as president of the Austrian Air Club. During World War I, von Economo served firstly on the Russian front, and later as a pilot on the southern front in the Tyrol region. He was also artistic, as his various works in the field of neuroanatomy clearly demonstrate ${ }^{4,7,9,10,18}$.

In conclusion, Constantin Freiheer von Economo was a neuroscientist of extraordinary intellect and scientific production who made magnanimous contributions to neurology through his description of lethargic epidemic encephalitis, the publication of his atlas on the cytoarchitecture of the adult human cerebral cortex, as well as multiple studies on neuroanatomy, neurophysiology, and clinical neurology. His exceptional skills extended into other nonmedical fields including aeronautics and arts.

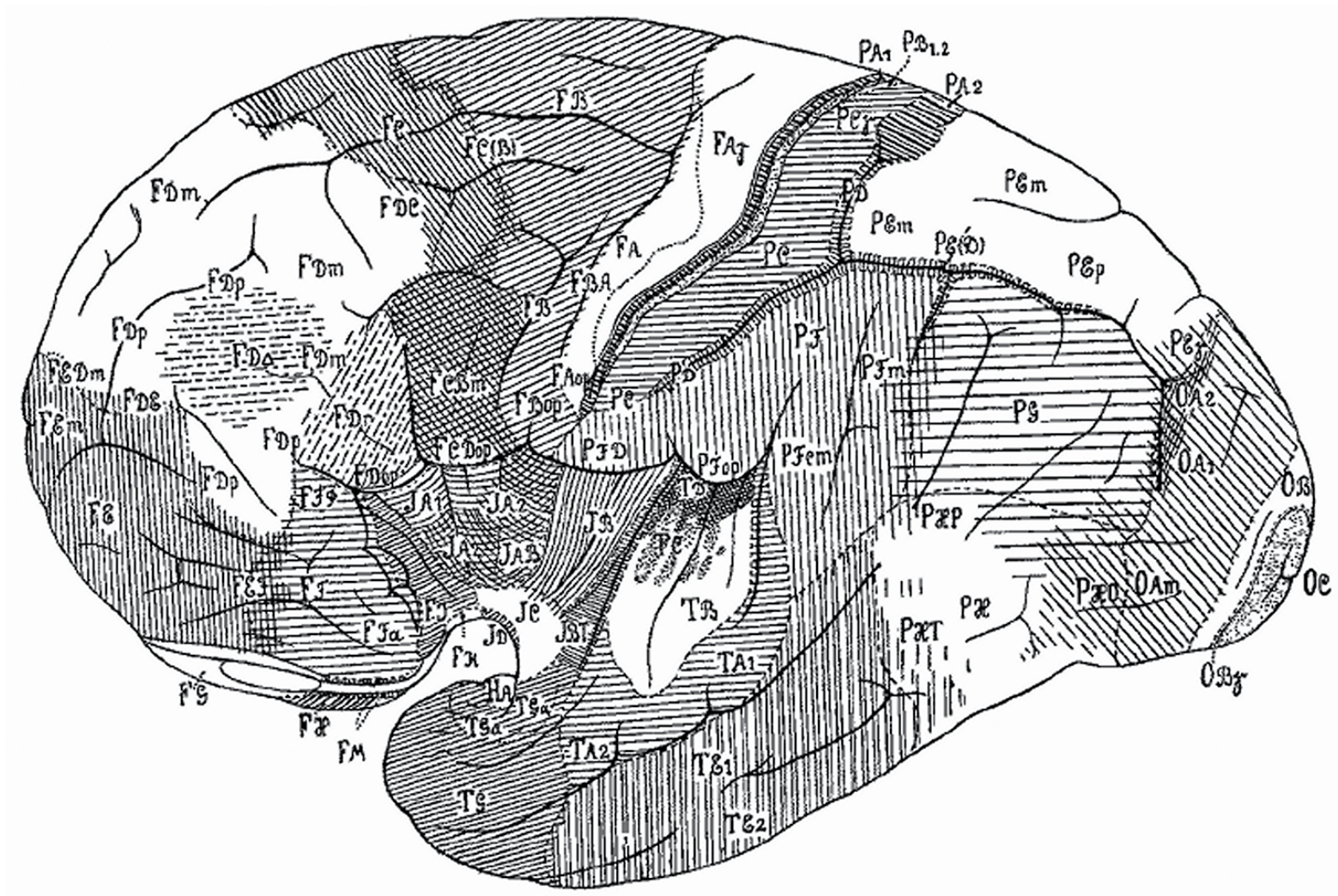

Abb. 3.

Extracted from https://commons.wikimedia.org/wiki/File:Constantin_von_Economo\%27s_cytoarchitectonic_chart_of_the_human_brain.png Figure 2. Constantin von Economo's cytoarchitectonic chart of the human brain in Atlas of Cytoarchitectonics of the Adult Human Cerebral Cortex.. 


\section{REFERENCES}

1. Hoffman LA, Vilensky JA. Encephalitis lethargica: 100 years after the epídemic. Brain. 2017 Aug 1;140(8):2246-51. https://doi.org/10.1093/ brain/awx177

2. Reid AH, McCall S, Henry JM, Taubenberger JK. Experimenting on the past: the enigma of von Economo's Encephalitis lethargica. J Neuropathol Exp Neurol. 2001 Jul 1;60(7):663-70. https://doi. org/10.1093/jnen/60.7.663

3. Dickman MS. Von Economo encephalitis. Arch Neurol. 2001 Oct;58(10):1696-8. https://doi.org/10.1001/archneur.58.10.1696

4. Triarhou LC. Pioneers in neurology: Constantin von Economo (18761931). J Neurol. 2007 Apr;254:550-1. https://doi.org/10.1007/s00415006-0308-7

5. Pearce JM. Baron Constantin von Economo and encephalitis lethargica.J Neurol Neurosurg Psychiatry. 1996 Feb;60(2):167. https://doi.org/10.1136/jnnp.60.2.167

6. Kyle RA, Shampo MA. Constantin von Economo.JAMA. 1978 Aug 11;240(6):568. https://doi.org/10.1001/jama.240.6.568

7. Jellinger KA. A short history of neurosciences in Austria.J Neural Transm (Vienna). 2006 Mar;113(3):271-82. https://doi.org/10.1007/ s00702-005-0400-7

8. Sak J, Grzybowski A. Brain and aviation: on the 80th anniversary of Constantin von Economo's (1876-1931) death. Neurol Sci. 2013 Mar;34(3):387-91. https://doi.org/10.1007/s10072-012-1111-0

9. Demetriades AK. From encephalitis lethargica to cerebral cytoarchitectonics: the polymath talento of Constantin von Economo (1876-1931), pioneer neuroanatomist, neurophysiologist and military aviator. Scott Med J. 2012 Nov 8;57(4):232-6. https://doi.org/10.1258/ smj.2012.012108

10. Triarhou LC. The signaling contributions of Constantin von Economo to basic, clinical and evolutionary neuroscience. Brain Res Bull. 2006 Apr 14;69(3):223-43. https://doi.org/10.1016/j. brainresbull.2006.02.001
11. Economo CJ. Die centralen Bahnen des Kau- und Schluckactes. Pflüger Arch. 1902 Sep;91:629-43. https://doi.org/10.1007/ BF01659665

12. Petousi VG, Proios H, Triarhou LC. The physiological experiments of Constantin von Economo on the central pathways of mastication and deglutition. Rev Neurol (Paris). 2019 Oct;175(9):506-18. https://doi. org/10.1016/j.neurol.2018.10.009

13. von Economo CF. Encephalitis lethargica. Wiener Klin Wochenschr. 1917;30:581-5.

14. Dale RC, Church AJ, Surtees RAH, Lees AJ, Adcock JE, Harding B, et al. Encephalitis lethargica syndrome: 20 new cases and evidence of basal ganglia autoimmunity. Brain. 2004 Jan 1;127(1):21-33. https:// doi.org/10.1093/brain/awh008

15. von Economo CF, Koskinas GN. Atlas of cytoarchitectonics of the adult human cerebral córtex. 1st ed. Basel: Karger; 2008. 182p.

16. Triarhou LC. The Economo-Koskinas atlas revisited: cytoarchitectonics and functional context. Stereotact Funct Neurosurg. 2007 Aug;85(5):195-203. https://doi. org/10.1159/000103258

17. Allman JM, Tetreault NA, Hakeem AY, Manaye KF, Semendeferi K, Erwin JM, et al. The von Economo neurons in the frontoinsular and anterior cingulate cortex. Ann N Y Acad Sci. 2011 Apr 28;1225(1):5971. https://doi.org/10.1111/j.1749-6632.2011.06011.x

18. Lavie P. The sleep theory of Constantin von Economo.J Sleep Res. 1993 Sep;2(3):175-8. https://doi.org/10.1111/j.1365-2869.1993. tb00083.x

19. Ransmayr G. Constantin von Economo's contribution to the understanding of movement disorders. Mov Disord. 2007 Mar 27;22(4):469-75. https://doi.org/10.1002/mds.21352

20. Thriarhou LC. Constantin von Economo's last publication: a commentary on Charles Fraiport’s “Évolution cérébrale". Acta Med Hist Adriat. 2016 Dec;14(2):387-92. 